\title{
Lessons Learned from Second Chances Campaign
}

$\mathrm{A}_{\text {voting rights since the passage of the Voting Rights }}^{\text {mendment } 4 \text { has been called the largest expansion of }}$ Act in $1965 .{ }^{14}$ In every way, it was a triumph for democracy both in the structure and process of the campaign and in the actual passage of the measure. While the victory takes on even greater significance in the context of the history of felon disenfranchisement and with consideration of the future opportunity to transform Florida by bringing more voices to the ballot box, we navigated many challenges to get here. And, as I'll discuss in the final section of this essay, we face similar challenges in the implementation of the victory if it is to have real impact on the lives of returning citizens. But first, let us take some useful lessons.

Directly impacted people provided an authentic voice to our campaign and drove the volunteer effort forward. They 
were at the heart of the Amendment 4 strategy. Post-victory, in the implementation phase, these returning citizens continued (and continue to this day) to play an equally critical role in ensuring that the strategy is accountable to the people it is intended to serve.

The Florida Rights Restoration Coalition led the Amendment 4 effort, but as the organization came to be increasingly prominent, it has become more organized and more structured. It is no longer a loose configuration of experts and allies. Today, the FRRC is a chapter-based membership organization consisting of formerly incarcerated people and their families from throughout the state. The FRRC also partners with an array of national and state allies and advocates to advance our mission to protect and implement Amendment 4 and also to connect the Amendment 4 victory to a longerterm agenda to advance policies that end mass incarceration, stop racial profiling and unfair policing, promote positive reentry policies, destigmatize returning citizens, and ensure improved public safety for all.

There is sometimes an inclination in truly transformational campaigns to romanticize strategy and downplay methodology. But in the case of the Second Chances campaign, there's been significant analysis of the deliberate choices that directly contributed to the campaign's success. That's because those same choices will be required in the subsequent phases of work to implement, defend, and protect 
the new law over the coming years. It can also help others who are engaged in efforts like these in their home states.

\section{Authentic Leadership of Impacted People}

he leadership by returning citizens was a lynchpin in
the multidimensional campaign strategy. It helped preempt partisanship, define the narrative, manage relationships with allies and partners who might have otherwise coopted the campaign, and laid the groundwork for building a constituency beyond passage.

Political campaigns very commonly feature impacted individuals in press events, messaging, ads, and other roles that can lend credibility to the effort and help shape their narrative. Often, these people are tokenized, used as props, and excluded from meaningful decision-making when larger, more well-resourced groups come into a state to support a campaign. We had similar experiences with Amendment 4, but we leveraged our constituency and allies who were committed to our vision of returning citizen leadership, thus preventing us from being "bigfooted" by outside groups who ultimately were not long-term stakeholders in the Amendment 4 fight. Moreover, we benefited by having former felons who were themselves affected by this issue as the actual developers, drivers, and leaders of the strategy. Having 
agency, and even leadership, not just being the face of the campaign, is highly unusual and was sometimes controversial; some "experts" had other ideas about best ways to win.

The participation of returning citizens at every level ensured that the campaign stayed accountable to its constituency. No matter what other political or policy interests might lurk among partners, the increased participation of returning citizens in the electorate served as reminders that reenfranchisement served everyone's interests, not just those of politicians who view these newly eligible voters as pawns in a larger game of power.

\section{Anticipating and Preempting Opposition}

ews coverage of the Amendment 4 campaign noted
time and again that there was very limited organized opposition to the ballot measure, certainly much less than anyone anticipated given the history of Florida. Limited opposition, however, was not an accident. It was an outcome accomplished by design. The campaign strategy from conception to implementation incorporated tactics designed to preempt and derail potential opposition, including opposition tactics that might leverage race, partisanship, or other polarizing elements to divide the electorate.

Among the most important steps to preempt potential opposition was the engagement of legal experts in drafting, 
vetting, and qualifying the ballot language. Lawyers from the NAACP, League of Women Voters, Advancement Project, ACLU, Brennan Center, and other allied groups played a critical role in helping forestall potential challenges from the Florida Supreme Court. Their work also informed the process we used to collect, validate, and submit signatures to qualify the measure at every step. Even in the implementation phase, a volunteer committee of many of the same lawyers continued to meet in preparation for potential state legislative challenges to the measure as well as to facilitate the county-by-county implementation of voter registration.

\section{Nonpartisan Outreach and Bipartisan Consensus}

he legal preparation to preempt opposition undergirded
more public aspects of the campaign, as well, like narrative and field organizing. In both of these arenas, faithbased allies and outreach to returning citizens (no matter what their political affiliation) were critical features of our work. The campaign deliberately drove a values-based message that promoted consensus across constituencies and went beyond the specific issue of felony disenfranchisement. We stressed fairness, redemption, and hope.

The campaign didn't just "talk the talk" of consensus. It was actually built to reflect the very values it promoted. The 
bipartisan coalition included groups across the ideological spectrum, bringing together returning citizens from all over the state, from every race and ethnicity, and from all kinds of backgrounds. At the FRRC, our leadership included both women and men, Black and White returning citizens, and people from left- and right-leaning political backgrounds.

My close partner Neil was quoted in a news outlet as saying: "This is an issue that transcends the rural-urbansuburban divide. It transcends the partisan divide. And it really is something that impacts all communities and all walks of life." 15 The FRRC pushed the coalition to adhere to a balanced approach and to avoid the appearance of partisanship, even though it sometimes caused tension with the progressive Democratic groups whose political positions and language on other issues could be conflated with our specific agenda on Amendment 4. Progressive organizations might frame the initiative as "us against the conservatives" and use language like the "right to vote" (as opposed to voting being a privilege); these tend to create hard lines that prevent an opportunity for concession. We felt that it was important to create an environment that, at the minimum, allowed the opportunity for someone who instinctively opposes our efforts to be moved in our direction.

The campaign also received endorsements from a variety of organizations and public figures, which demonstrated its broad appeal. Among the endorsing organizations were the Florida Conference of Catholic Bishops, the National 
Education Association, Our Revolution, and the Libertarian Party of Florida. High-profile leaders and celebrities also lent their support to the campaign, including the singer John Legend, Mark Holden (the chair of the Freedom Partners Chamber of Commerce), and an assortment of NBA and NFL athletes.

As it turns out, transcending partisanship proved to be a critical part of securing enough votes to pass the measure. Amendment 4 passed on November 6, 2018, with 64.5 percent of the vote. The statewide measure received more votes than any statewide candidate, including over one million votes from Republicans. The years of outreach, building a powerful grassroots groundswell of support, and statewide networks of relationships paid off on election day. But our task was then to see if they would continue to create capacity for implementation. 